\title{
In vivo Antineoplastic Activities of Benzoin Thiosemicarbazone and Para-Anisaldehyde Semicarbazone against Ehrlich Ascites Carcinoma Cells
}

Mohsin Ali $^{1}$, Mele Jesmin ${ }^{1}$, Sarozit Mondal ${ }^{1}$, Abu Rashed $^{1}$, Khairul Islam ${ }^{1}$

${ }^{1}$ Department of Applied Chemistry and Chemical Engineering, University of Rajshahi, Rajshahi, Bangladesh.

\section{ABSTRACT}

Two Schiff bases, namely benzoin thiosemicarbazone (BTSC) and para-anisaldehyde semicarbazone (PAS), were synthesized and characterized. The antineoplastic activities of these Schiff bases were studied against Ehrlich ascites carcinoma (EAC) cells in Swiss albino mice by monitoring tumor cell growth inhibition, tumor weight measurement, survival time of tumor-bearing mice, bioassay of these compounds, and counting the total number of peritoneal cells as well as macrophages. Hematological parameters were also studied. It was found that these compounds significantly reduced tumor cell growth rate, decreased tumor weight, and increased life span of EAC-bearing mice. These test compounds restored the hematological parameters of EAC-bearing mice to normal. These compounds also enhanced the number of macrophages in normal mice. The results obtained were compared with those obtained with the standard drug bleomycin.

Key words: Antineoplastic activity, benzoin thiosemicarbazone, EAC cells, para-anisaldehyde semicarbazone

\section{INTRODUCTION}

Cancer, which is a diverse group of diseases characterized by proliferation and spread of abnormal cells, is a major worldwide concern. Therefore, the discovery and development of new potent and selective anticancer drugs are of high importance in modern cancer research. Schiff bases containing the $C=N$ group play a very important role in many biological activities. They have been found to possess anticancer (1,2), antimicrobial (3), antitubercular (4), antiinflammatory and anlgesic (5), antiviral (6), and pesticidal (7) properties. Not only the Schiff bases, but also Schiff base complexes with transition metals have been investigated for their anticancer activities against Ehrlich ascites carcinoma (EAC) cells in Swiss albino mice $(8,9)$. Recently, the anticancer activities of some semicarbazones and thiosemicarbazones against EAC cells have been reported (10-12). The aim of the present study was to explore the anticancer properties of two Schiff bases, namely benzoin thiosemicarbazone (BTSC) and para-anisaldehyde semicarbazone (PAS).

\section{MATERIALS AND METHODS}

Chemicals

All chemicals and reagents used to carry out the research work were of reagent grade.

Experimental animals

Swiss albino mice, 5-7 weeks old and weighing 25-30 g, were collected from International Centre for Diarrhoeal Disease Research, Bangladesh (ICDDR'B) Mohakhali, Dhaka.

Animal care

Mice were kept in iron cages with saw dust and straw bedding, which was changed once a week regularly. Standard mouse diet (recommended and prepared by ICDDR'B) and water were given adequately. 


\begin{tabular}{|c|c|c|c|c|c|}
\hline $\begin{array}{l}\text { Test } \\
\text { compounds }\end{array}$ & $\begin{array}{l}\text { Yield } \\
(\%)\end{array}$ & $\begin{array}{l}\text { Melting point } \\
\left({ }^{\circ} \mathrm{C}\right)\end{array}$ & $\begin{array}{l}\text { Physical } \\
\text { form }\end{array}$ & Solubility & $\begin{array}{l}\text { IR Spectra } \\
\left(\mathrm{cm}^{-1}\right)\end{array}$ \\
\hline BTSC & 60 & $150-153^{15}$ & $\begin{array}{l}\text { White } \\
\text { Crystalline }\end{array}$ & Ethanol DMSO & $\begin{array}{l}3164(-\mathrm{NH}-), 1284(-\mathrm{C}=\mathrm{N}-\mathrm{NH}), 940 \\
(-\mathrm{C}=\mathrm{S}), 1607(>\mathrm{C}=\mathrm{N}-)\end{array}$ \\
\hline PAS & 65 & $204-207^{14}$ & $\begin{array}{l}\text { White } \\
\text { Crystalline }\end{array}$ & Ethanol, DMSO & $\begin{array}{l}1650(>\mathrm{C}=\mathrm{N}), 1690(>\mathrm{C}=\mathrm{O}), 3500 \\
\left(-\mathrm{CONH}_{2}\right)\end{array}$ \\
\hline
\end{tabular}

\section{Ethical clearance}

The protocol used in this study for the use of mice as the animal model for research was approved by the University Animal Ethical Committee (27/08/RUBCMB).

Synthesis of the compounds

These compounds were synthesized according to the method described in the literature (10-14). For preparing BTSC, benzoin and thiosemicarbazide were mixed in 1:1 molar ratio, refluxed for a period of $3-4 h$, and then distilled to half of the total volume. The solution was then allowed to stand overnight till a white crystalline product separated out. The crystals were washed with ethanol, recrystallized, finally dried in an oven at $50^{\circ} \mathrm{C}$, and stored in a desiccator.
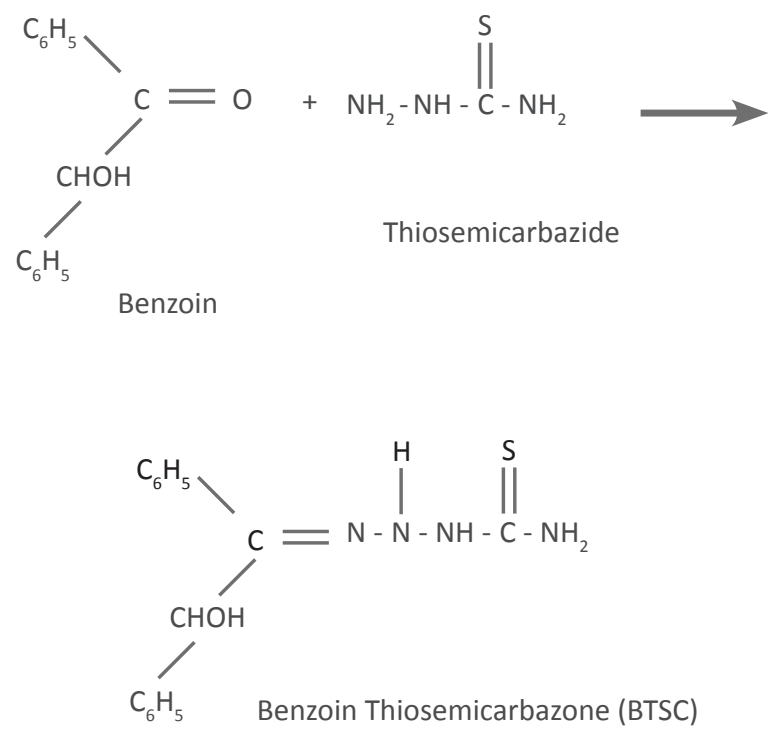

For preparing PAS, para-anisaldehyde and semicarbazide (1:1 molar ratio) were mixed together and the same procedure was followed as used for BTSC.<smiles>CNC(=O)NNOC(=O)c1ccc(OC)cc1</smiles>

Para-anisaldehyde Semicarbazide<smiles></smiles>

Characterization of Schiff bases

The synthesized compounds were characterized by evaluating the melting point and IR spectra (on KBr disk using a Shimadzu FTIR) (Table 1).

Cell lines

Ehrlich ascites carcinoma (EAC) cells were obtained by the courtesy of Indian Institute of Chemical Biology (IICB), Kolkata, India. The cells were maintained as ascites tumor in Swiss albino mice by intraperitoneal inoculation (biweekly) of $2 \times 10^{6}$ cells/mouse.

Toxicity study

An acute toxicity study related to the determination of $L D_{50}$ was performed using the conventional method (16). The compounds were dissolved in 2\% dimethyl sulfoxide (DMSO) and injected intraperitoneally into six groups of mice (each containing six mice) in different doses. $L_{50}$ values were evaluated by recording mortality after $24 \mathrm{~h}$.

\section{Cell growth inhibition}

In vivo tumor cell growth inhibition was carried out using the method as described (10-12) earlier. For this study, eight groups of mice (six in each group) were used. All the mice were injected with EAC cells ( $0.1 \mathrm{~mL}$ of $2 \times 10^{6}$ cells/mouse) intraperitoneally. 
Treatment was started after $24 \mathrm{~h}$ of tumor inoculation and continued for 6 days. Groups 1-3 were treated with BTSC at the doses of $4 \mathrm{mg} / \mathrm{kg}, 8 \mathrm{mg} / \mathrm{kg}$, and $16 \mathrm{mg} / \mathrm{kg}$ (i.p.), respectively. Groups 4-6 were treated with PAS at the doses of $10 \mathrm{mg} / \mathrm{kg}$, $20 \mathrm{mg} / \mathrm{kg}$, and $30 \mathrm{mg} / \mathrm{kg}$ (i.p.), respectively. Group 7 received standard drug bleomycin $(0.3 \mathrm{mg} / \mathrm{kg}$, i.p.). Group 8, treated with only normal saline (0.98\%), was considered as untreated control. The mice of all the groups were sacrificed on the 6th day after transplantation, and tumor cells were collected by repeated intraperitoneal wash with $0.98 \%$ saline. Viable tumor cells per mouse of the treated groups were compared with those of control. The cell growth inhibition was calculated using the following formula:

$\%$ Cell growth inhibition $=\left(1-I_{w} / C_{w}\right) \times 100$, where $I_{w}=$ mean of number of tumor cells of the treated group of mice $C_{w}=$ mean of number of tumor cells of the control group of mice.

\section{Average tumor weight and survival time}

The antitumor activities of BTSC and PAS were assessed (17) by measuring the average tumor weight, mean survival time (MST), and percentage increase in life span (\%ILS). The treatment was continued for 10 days. Tumor growth was monitored daily by measuring the change in weight. MST of each group was monitored by recording the survival time. MST and \%ILS were calculated using the following equations.

MST = Survival time (days) of each mouse in a group/ Total number of mice

Percent increase in life span,

\%ILS $=($ MST of treated group $/$ MST of control group) $\times 100$

\section{Bioassay of EAC cells}

The procedure was a modification of the methods used in the literature (18). Three groups of mice (four in each) were inoculated with $2 \times 10^{6}$ EAC cells. Group 1 was treated with BTSC at the dose of $16 \mathrm{mg} / \mathrm{kg}$ (i.p), and Group 2 was treated at the dose of $30 \mathrm{mg} /$ $\mathrm{kg}$ (i.p), for five consecutive days. Group 3 served as control. On day 6 , mice of all the groups were sacrificed and tumor cells from each group were harvested in cold saline (0.98\%), pooled, and centrifuged. These cells were re-inoculated $\left(2 \times 10^{6}\right.$ cells/mouse i.p.) into three fresh groups of mice $(n=4)$ as earlier. No further treatment was given to these mice. On day 5, mice from each group were sacrificed and tumor cells per mouse were counted and compared with that of control.

\section{Hematological studies}

The hematological parameters, namely WBC, RBC, and hemoglobin contents, were determined by the standard methods (19) using cell dilution fluids and hemocytometer. Blood was collected from the mice by tail puncture. Nine groups of mice ( $n=4)$ were used for this test. Groups 1-3 were treated with BTSC at the doses of $4 \mathrm{mg} / \mathrm{kg}, 8 \mathrm{mg} / \mathrm{kg}$, and $16 \mathrm{mg} / \mathrm{kg}$ (i.p.), and groups 4-6 were treated with PAS at the doses of $10 \mathrm{mg} /$ $\mathrm{kg}, 20 \mathrm{mg} / \mathrm{kg}$, and $30 \mathrm{mg} / \mathrm{kg}$ (i.p.), respectively. Group 7 was used as control, Group 8 comprised normal mice, and Group 9 was treated with standard drug bleomycin $0.3 \mathrm{mg} / \mathrm{kg}$ (i.p.). Treatment started after $24 \mathrm{~h}$ of tumor transplantation and was continued for 10 consecutive days. On days 5, 10, 15, and 25, the blood parameters were assayed for all the groups.

Determination of the effect of Schiff bases on normal peritoneal cells

The effects of Schiff bases on normal peritoneal cells were determined (20) by counting total peritoneal cells and macrophages. Two groups of mice (four in each) were treated with BTSC and PAS separately at the dose of $16 \mathrm{mg} / \mathrm{kg}$ and $30 \mathrm{mg} /$ $\mathrm{kg}$ (i.p.), respectively, for three consecutive days. The untreated group was used as control. After 24 hours of the last treatment, each animal were injected with $5 \mathrm{~mL}$ of normal saline (0.98\%) into the peritoneal cavity and then sacrificed. Intraperitoneal exuded cells and macrophages were counted with 1\% neutral red using a hemocytometer.

\section{Statistical analysis}

The experimental results were expressed as the mean \pm SEM. Data were calculated using one-way analysis of variance followed by Dunnett t test using SPSS software version 10 (An IBM Company, IBM Corporation, 1 New Orchard Road, Armonk, New York 10504, 1722, United States). 
TABLE 2: Effect of the Schiff bases and bleomycin on cell growth inhibition

\begin{tabular}{|c|c|c|c|}
\hline Experiment & $\begin{array}{c}\text { Dose } \\
\text { (mg/kg, i.p.) }\end{array}$ & $\begin{array}{l}\text { No. of EAC cells in mice } \\
\text { on day } 6 \text { after tumor cell } \\
\text { inoculation }\left(\times 10^{7}\right)\end{array}$ & $\begin{array}{l}\text { \% Cell growth } \\
\text { inhibition }\end{array}$ \\
\hline Control (untreated EAC cell-bearing mice) & - & $2.517 \pm 0.182$ & - \\
\hline $\mathrm{EAC}+$ Bleomycin & 0.3 & $0.297 \pm 0.012 * * *$ & 88.2 \\
\hline \multirow[t]{3}{*}{$\mathrm{EAC}+\mathrm{BTSC}$} & 4 & $0.99 \pm 0.014 * * *$ & 60.61 \\
\hline & 8 & $0.66 \pm 0.02 * * *$ & 73.53 \\
\hline & 16 & $0.32 \pm 0.003 * * *$ & 87.24 \\
\hline \multirow[t]{3}{*}{$E A C+P A S$} & 10 & $2.324 \pm 0.05 * *$ & 35.77 \\
\hline & 20 & $1.426 \pm 0.043^{* * *}$ & 60.58 \\
\hline & 30 & $0.857 \pm 0.075^{* * *}$ & 76.29 \\
\hline
\end{tabular}

\section{RESULTS}

The toxicity of these compounds was evaluated by measuring $\mathrm{LD}_{50}$ values. For BTSC and PAS, the values were found to be 75 and $220 \mathrm{mg} / \mathrm{kg}$ (i.p.), respectively.

In vivo tumor cell growth was observed with BTSC at doses 4 $\mathrm{mg} / \mathrm{kg}, 8 \mathrm{mg} / \mathrm{kg}$, and $16 \mathrm{mg} / \mathrm{kg}$ (i.p.) Maximum cell growth inhibition (87.24\%) was found after treatment with BTSC at the dose of $16 \mathrm{mg} / \mathrm{kg}$ (i.p.). Treatment with PAS the dose of $30 \mathrm{mg} /$ $\mathrm{kg}$ (i.p.) resulted in cell growth inhibition by $76.29 \%$. On the other hand, bleomycin at the dose of $0.3 \mathrm{mg} / \mathrm{kg}$ (i.p.) inhibited the cell growth by $88.2 \%$ (Table 2).

The mean survival time (MST) of the untreated tumor-bearing mice was 23 days. With the treatment of test compounds, this value increased. About $78.26 \%$ enhancement of life span was found with $16 \mathrm{mg} / \mathrm{kg}$ (i.p.) BTSC and 55.29\% with $30 \mathrm{mg} / \mathrm{kg}$ (i.p.) PAS at (Table 3).

TABLE 3: Effect of the Schiff bases and bleomycin on cell growth inhibition

\begin{tabular}{|c|c|c|c|}
\hline Treatment & $\begin{array}{l}\text { Dose } \\
\text { (mg/kg) (i.p.) }\end{array}$ & $\begin{array}{l}\text { Mean survival time mean } \\
\pm \text { SEM (days) }\end{array}$ & $\%$ Increase in life span \\
\hline Control (untreated EAC cell-bearing mice) & - & $23 \pm 0.98$ & - \\
\hline EAC + Bleomycin & 0.3 & $43 \pm 0.86 * * *$ & 86.95 \\
\hline \multirow[t]{3}{*}{$\mathrm{EAC}+\mathrm{BTSC}$} & 4 & $31 \pm 0.88^{*}$ & 34.78 \\
\hline & 8 & $34 \pm 1.09 * *$ & 47.82 \\
\hline & 16 & $41 \pm 0.99 * *$ & 78.26 \\
\hline \multirow[t]{3}{*}{$E A C+P A S$} & 10 & $27 \pm 1.45^{*}$ & 23.53 \\
\hline & 20 & $30 \pm 2.25^{* *}$ & 38.82 \\
\hline & 30 & $33 \pm 1.5^{* * *}$ & 55.29 \\
\hline
\end{tabular}

Data are expressed as the mean of results in six mice \pm SEM. Treatment was continued for 10 consecutive days. Significance values were $* P<0.05$, $* * P<0.01$ and $* * * P<0.001$ when compared with the control. 


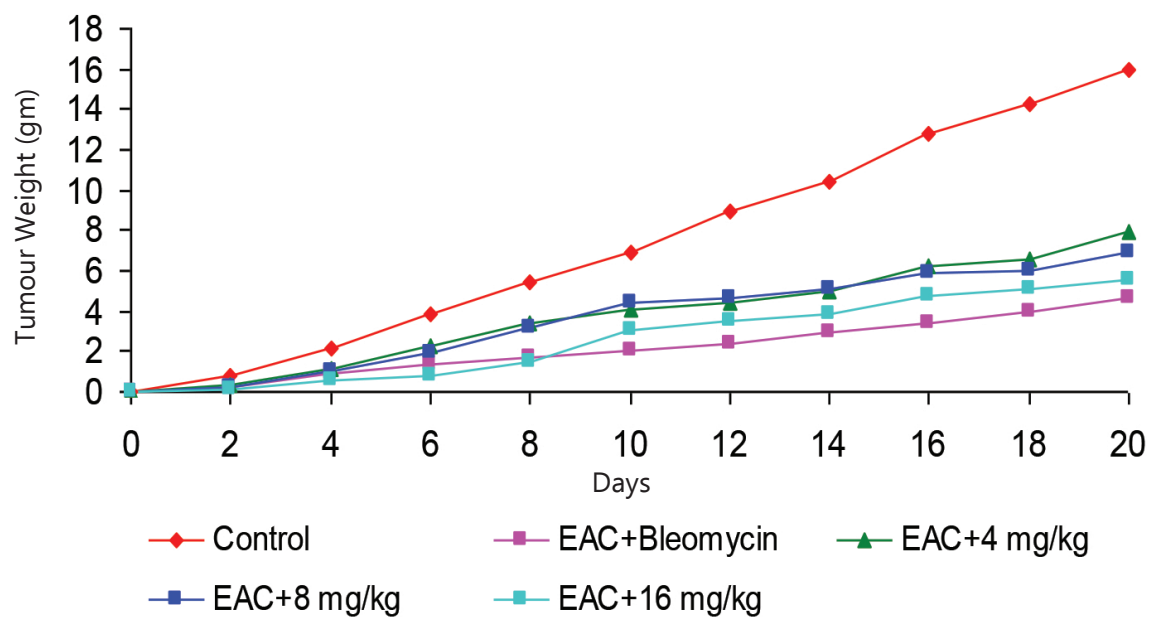

Data were expressed as the mean of results in six mice. Treatment was continued for 10 consecutive days.

FIGURE 1: Effect of BTSC on average tumor weight.

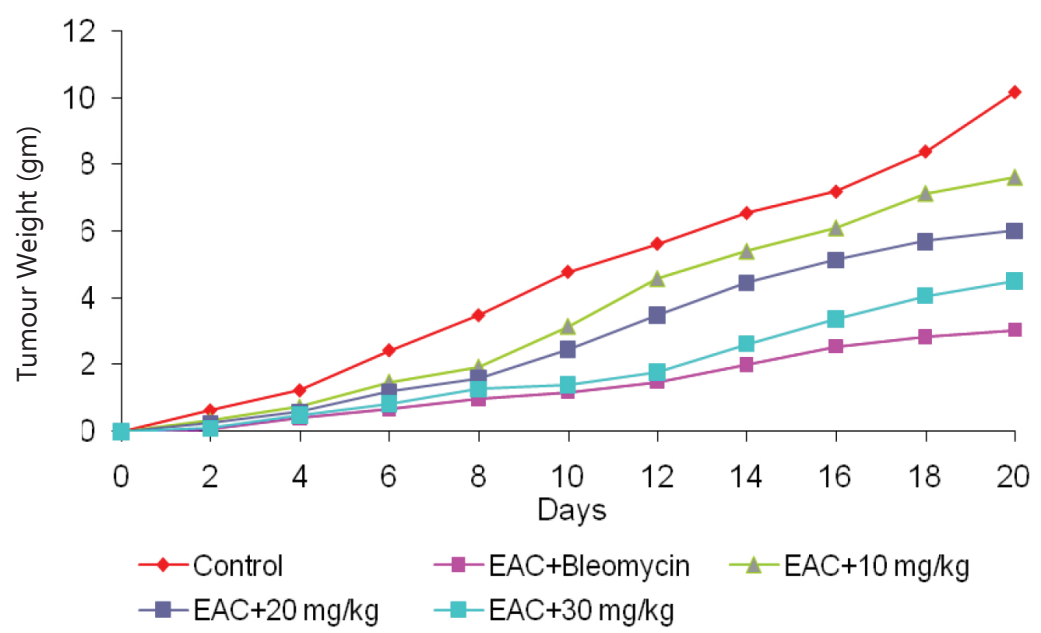

Data were expressed as the mean of results in six mice. Treatment was continued for 10 consecutive days.

FIGURE 2: Effect of PAS on average tumor weight.

The treatment with Schiff bases also reduced the rate of tumor growth. At day 20, BTSC at the dose of $16 \mathrm{mg} / \mathrm{kg}$ (i.p.) and PAS at the dose of $30 \mathrm{mg} / \mathrm{kg}$ (i.p.) reduced the tumor weight by $65.05 \%$ and $55.70 \%$, respectively, compared with the control mice. Bleomycin at the dose of $0.3 \mathrm{mg} / \mathrm{kg}$ (i.p.) caused a reduction by 73.83\% (Figures 1 and 2).

The hematological parameters of both EAC cell-bearing mice and normal mice were examined. In EAC cell-bearing mice, all parameters (WBC, RBC, and hemoglobin content) were found to be significantly changed compared with those of the normal mice. The rate of deterioration, however, slowed down after the treatment (Figures 3-8). In case of parallel treatment of normal mice, these parameters slightly changed from the normal values. After 25 days of the initial treatment, they were restored to normal values.

The effect of Schiff bases on the loss of transplantability of EAC cells was observed by the reduction of intraperitoneal tumor growth in mice re-inoculated with test compound-treated EAC cells (Table 4) compared with control. Maximum reduction (67.88\%) of tumor growth was observed with BTSC at the dose of $16 \mathrm{mg} / \mathrm{kg}$ (i.p.), whereas PAS at $30 \mathrm{mg} / \mathrm{kg}$ (i.p.) reduced the transplantability of EAC cells by $58.03 \%$.

The compounds at highest experimental doses also enhanced the number of both peritoneal cells and macrophages, to some extent, in normal mice (Table 5). 


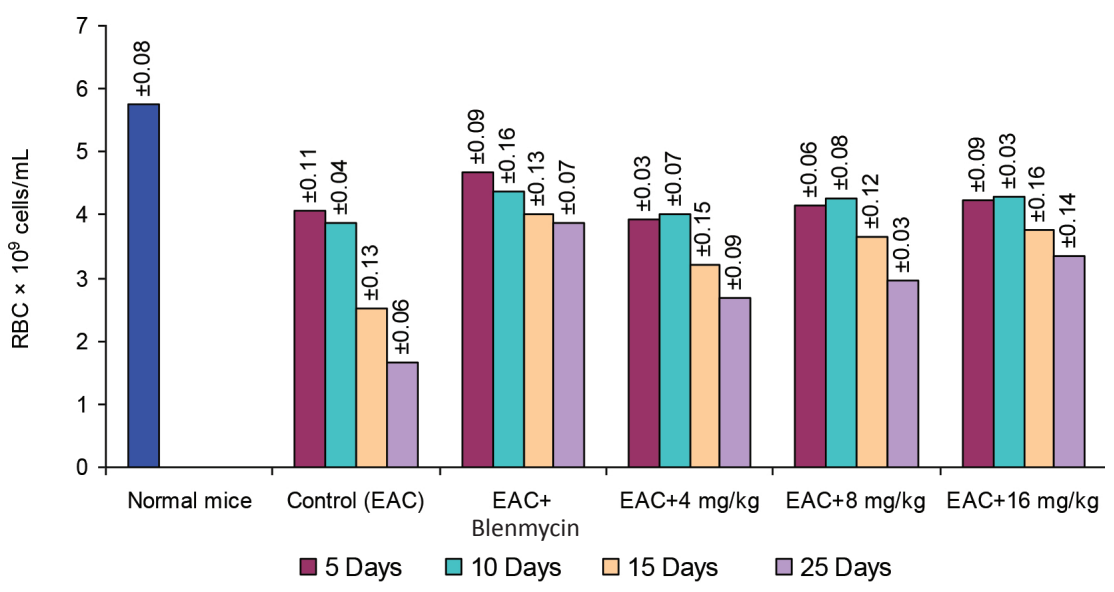

Data were expressed as the mean of results in four mice \pm SEM. Treatment was continued for 10 consecutive days.

FIGURE 3: Effect of BTSC on RBC content of EAC-bearing mice on days 5, 10, 15, and 25.

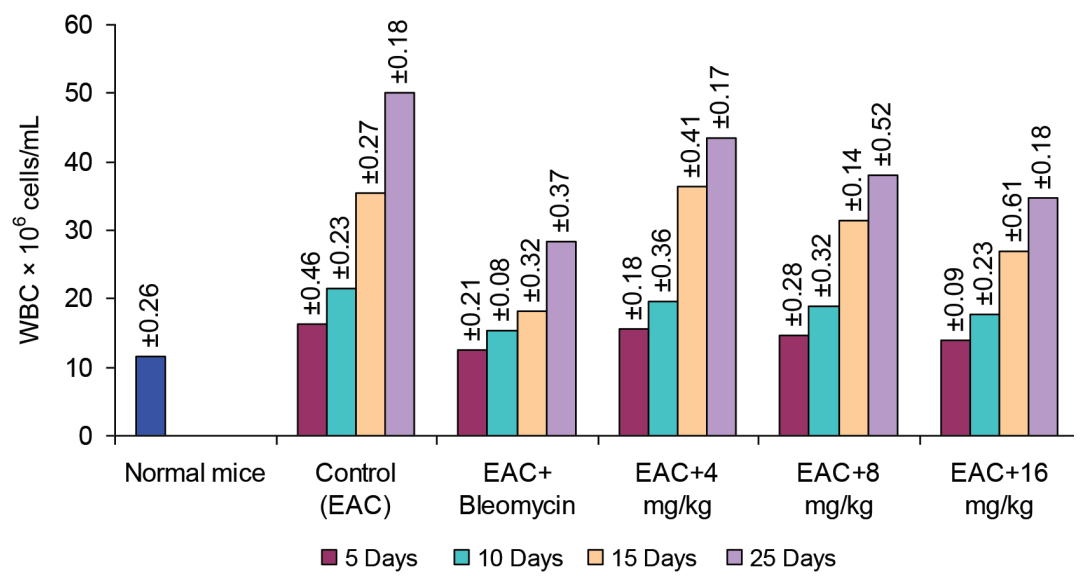

Data were expressed as the mean of results in four mice \pm SEM. Treatment was continued for 10 consecutive days.

FIGURE 4: Effect of BTSC (4 mg/kg [i.p.], $8 \mathrm{mg} / \mathrm{kg}$ [i.p.], and $16 \mathrm{mg} / \mathrm{kg}$ [i.p.]) on WBC content of EAC-bearing mice on days 5, 10, 15, and 25 .

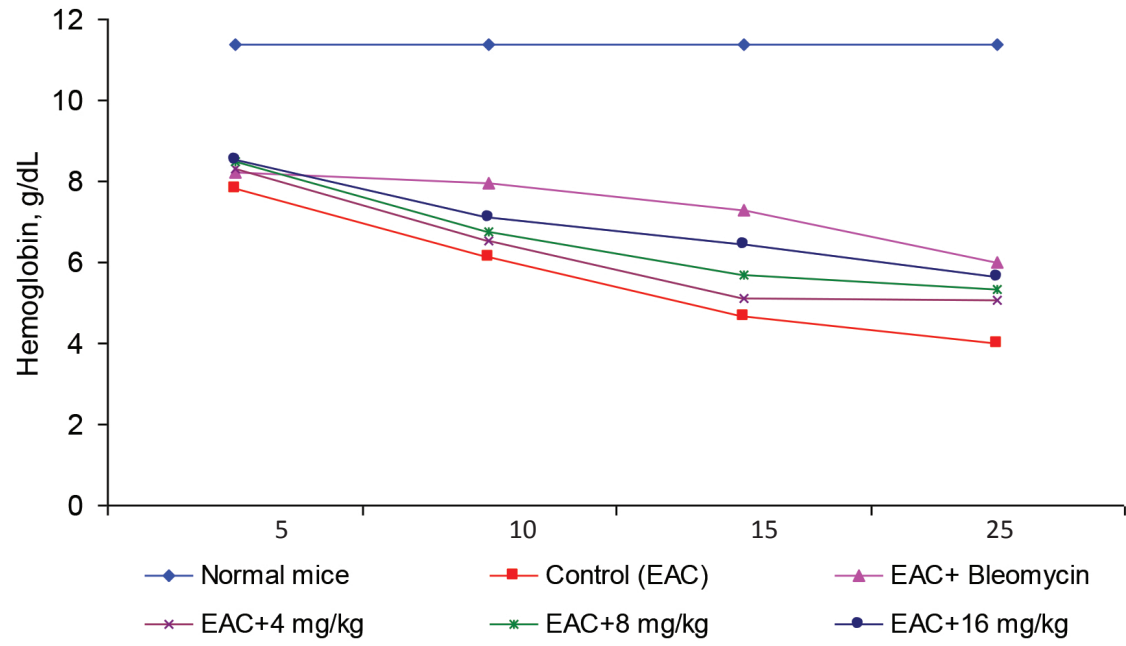

Data were expressed as the mean of results in four mice. Treatment was continued for 10 consecutive days.

FIGURE 5: Effect of BTSC on hemoglobin content of EAC-bearing mice on days 5, 10, 15, and 25. 


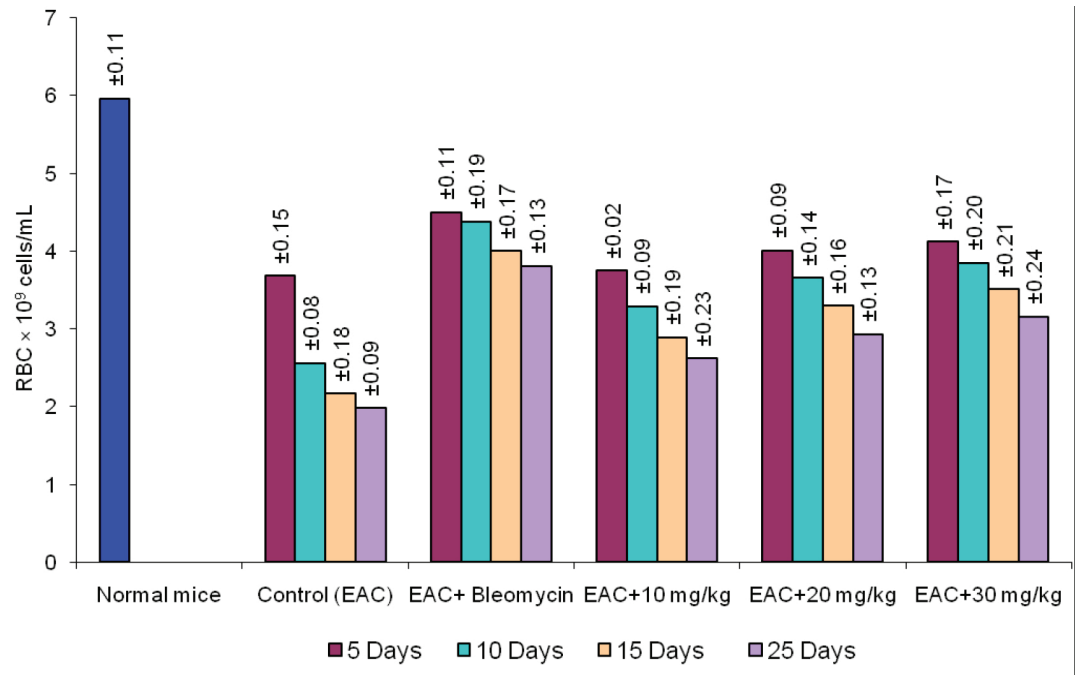

FigurE 6: Effect of PAS on RBC content of EAC-bearing mice on days 5, 10, 15, and 25.

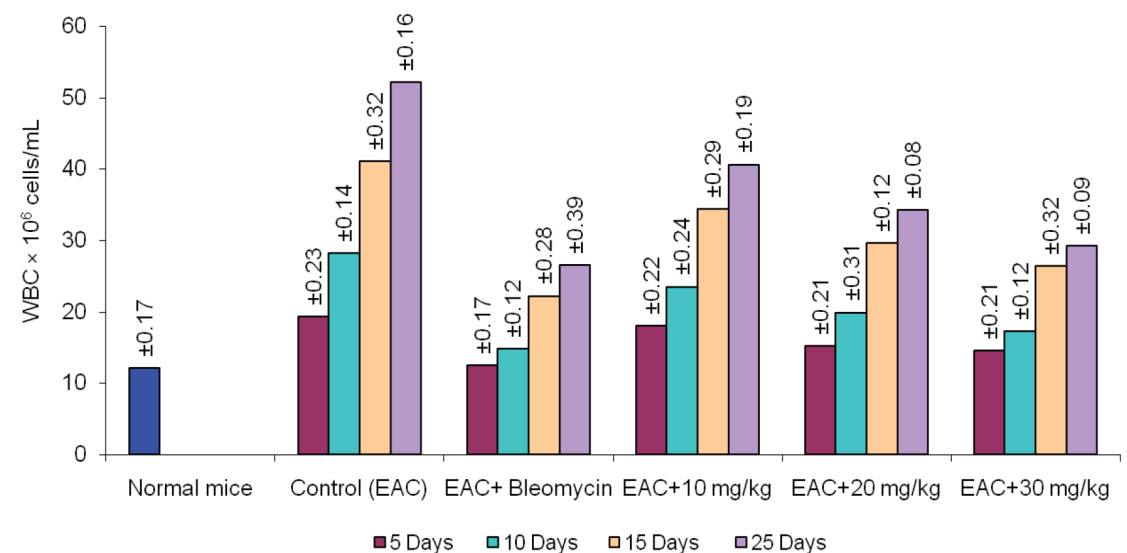

FiguRE 7: Effect of PAS on WBC content of EAC-bearing mice on days 5, 10, 15, and 25.

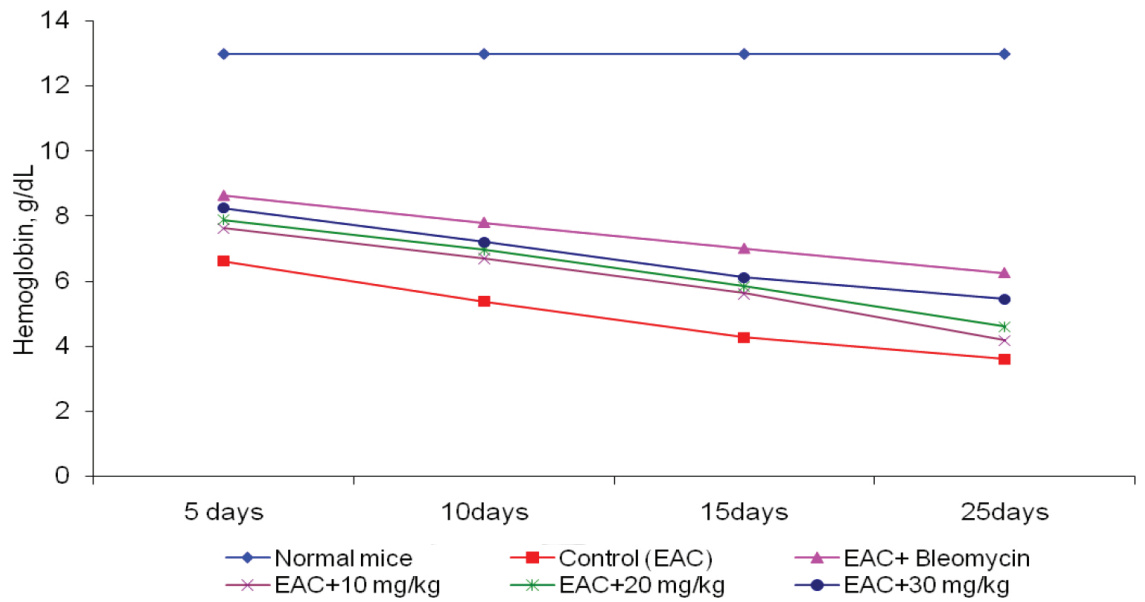

FIGURE 8: Effect of PAS on WBC content of EAC-bearing mice on days 5, 10, 15, and 25.
Data were expressed as the mean of results in six mice. Treatment was continued for 10 consecutive days.
Data were expressed as the mean of results in six mice. Treatment was continued for 10 consecutive days.
Data were expressed as the mean of results in six mice. Treatment was continued for 10 consecutive days. 


\begin{tabular}{|c|c|c|c|}
\hline Treatment & $\begin{array}{l}\text { Dose } \\
\text { (mg/kg i.p.) }\end{array}$ & $\begin{array}{l}\text { No. of EAC cells } \\
\left(\times 10^{7}\right)\end{array}$ & $\begin{array}{l}\text { Cell growth inhibition on inoculating EAC cells } \\
\text { with the drugs }\end{array}$ \\
\hline Control (untreated EAC cell-bearing mice) & - & $3.14 \pm 0.04$ & - \\
\hline $\mathrm{EAC}+\mathrm{BTSC}$ & 16 & $1.01 \pm 0.007 * * *$ & $67.88 \%$ \\
\hline$E A C+P A S$ & 30 & $1.32 \pm 0.05^{* *}$ & $58.03 \%$ \\
\hline
\end{tabular}

TABLE 5: Effect of the test compounds on the enhancement of normal peritoneal cells in mice

\begin{tabular}{llll}
\hline Treatment & $\begin{array}{l}\text { Dose } \\
(\mathrm{mg} / \mathrm{kg} \text { i.p.) }\end{array}$ & Macrophages (cells $/ \mathrm{mL}) \times 10^{6}$ & Total peritoneal cells $\times 10^{6}$ \\
\hline Control (normal) & - & $1.44 \pm 0.42$ & $3.82 \pm 0.29$ \\
Normal + BTSC & 16 & $1.75 \pm 0.34^{* *}$ & $4.26 \pm 0.16$ \\
Normal + PAS & 30 & $1.86 \pm 0.21^{* * *}$ & $4.43 \pm 0.32$ \\
\hline
\end{tabular}

Data were expressed as the mean of results in four mice \pm SEM. Treatment was continued for three consecutive days. ${ }^{* * * P}<0.001$ and ${ }^{* * P}<0.01$ when compared with the control.

\section{DISCUSSION}

The results of the present study showed that the two Schiff bases were capable of reducing average tumor weight and increasing the life span of tumor-bearing mice. In all cases, these abilities increased with increased doses of the compounds. BTSC $16 \mathrm{mg} /$ $\mathrm{kg}$ (i.p.) and PAS $30 \mathrm{mg} / \mathrm{kg}$ (i.p.) showed maximum values, which were quite comparable to those of bleomycin $0.3 \mathrm{mg} / \mathrm{kg}$ (i.p.).

Analogous results were obtained for EAC cell growth inhibition by these Schiff bases. With the increase in doses, the percentage of cell growth inhibition was found to increase noticeably.

All these results are considered to be very important and promising in justifying the potency of these compounds in cancer chemotherapy (21). The major problems usually encountered in cancer chemotherapy are myelosuppression and anemia $(22,23)$ due to the reduction of RBC and hemoglobin contents. This is probably owing to the deficiency of iron in hemolytic or myelopathic conditions (24). After treatment with each of the two synthesized compounds under investigation, all the hematological parameters were restored to normal. This can be inferred from the decreased rate of deterioration of these parameters on treatment with these drugs (Schiff bases and bleomycin). The toxic effects of these Schiff bases are not very high. This indicates that both BTSC and PAS have protective actions on the hematopoietic system. The rectifying ability for the hematological parameters in EAC-bearing mice has been demonstrated by the increase in life span and other parameters studied for evaluating the potency of these compounds as antineoplastic agents. The effects of BTSC and PAS on the viability of EAC cells are found to be reduced significantly. BTSC shows a better effect. In addition, the treatment in normal mice increases the number of macrophages and peritoneal cells, which plays an important role in destruction of cancer cells by phagocytosis (25). Macrophages may produce some cytokines such as tumor necrosis factor (TNF) and interleukins inside the peritoneal cavity, which in turn may be responsible for killing tumor cells26. Besides, high $\mathrm{LD}_{50}$ values represent the low toxicity of the compounds to the host.

So, BTSC and PAS are expected to be effective anticancer agents with low toxicities. However, the information obtained from the present study is insufficient for establishing BTSC and PAS as novel anticancer drugs in clinical practice. Many more investigations 
need to be carried out with these compounds using various other cancer cell lines and animals in order to substantiate the present findings.

\section{ACKNOWLEDGMENTS}

The authors are grateful to IICB (Kolkata, India) authority for providing the EAC cells and ICDDR'B (Dhaka, Bangladesh) for providing the mice and the standard mouse pellet.

\section{REFERENCES}

1. Jesmin M, Ali MM, Khanam JA. Antitumor activities of some schiff bases derived from benzoin, salicylaldehyde, amino phenol and 2,4, dinitrophenyl hydrazine. Thai J Pharm Sci 2010; 34: 20-31.

2. Xiang Li, Xue-Qiang Li, He-Meiliu, Xue-Zhang Zhou, Zhi-Hui Shao. Synthesis and evaluation of antitumor activities of novel chiral 1, 2, 4-traizole schiff bases bearing $\gamma$-butenolide moiety, Org Med Chem Let 2012; 2: 26-30.

3. Jesmin M, Ali MM, Salahuddin MS, Habib MR, Khanam JA Antimicrobial activities of some schiff bases derived from benzoin, salicylaldehyde, aminophenol and 2, 4- dinitrophenyl hydrazine. Mycol 2008; 36(1): 70-73.

4. Islam MR, Mirza AH, Huda QMW, Khan BR. The synthesis of some antitubercular agents, aldehyde thiosemicarbazones and 1, 2, 3-thiodiazotine derivatives. J Bang Chem Soc 1989; 2: 8995

5. Ali MM, Jesmin M, Azad MAK, Islam MK, Zahan R. Antiinflammatory and analgesic activities of acetophenone semicarbazone and benzophenone semicarbazone. Asian Pacific Journal of Tropical Biomedicine 2012; S: 1036-1039.

6. Boon R. Antiviral treatment: from concept to reality. Antiviral Chemistry and Chemotherapy 1997; 8: 5-10.

7. Ali MM, Jesmin M, Salam SMA, Khanam JA, Islam MF, Islam MN Pesticidal activities of some schiff bases derived from benzoin salicylaldehyde, aminophenol and 2,4-dimitrophenyl hydrazine. J Sci Res 2009;1(3): 641-646.

8. Ali MM, Jesmin M, Sarker MK, Salahuddin MS, Habib MR, Khanam JA. Antineoplastic activity of $\mathrm{N}$-salicyldene-glycinatodi-aquanickel (II) complex against Ehrlich ascites carcinoma (EAC) cells in mice. Int J Biol Chem Sci 2008; 2: 292-298.

9. Ali MM, Jesmin M, Islam MN, Shahrair SMS, Habib MR, Islam MF, Khanam JA. Anticancer activities of some transition metal complexes of a schiff base derived from salicylaldehyde and glycine. ACGC Chem Res Comm 2009; 23: 13-22.

10. Ali MM, Azad MAK, Jesmin M, Ahsan S, Rahman MM, Khanam JA, Islam MN, Shahriar SMS. In vivo anticancer activity of vanillin semicarbazone. A Pac J Trop Biomed 2012; 2 (6): 438-442.
11. Islam K, Ali MM, Jesmin M, Khanam JA. In vivo anticancer activities of benzophenone semicarbazone against Ehrlich ascites carcinoma (EAC) cells in swiss albino mice. Cancer Biol Med 2012; 9: 242-247.

12. Ali MM, Jesmin $M$, Islam MK, Khatun F, Azad AK. Antineoplastic activities of acetone thiosemicarbazone against Ehrlich ascites carcinoma cells bearing mice. Med J ISL W Aca Sci 2013; 21(3): 97-104.

13. Vogel AI. Elementary Practical Organic Chemistry Part-2: Qualitative Organic Analysis; 2nd ed., London, p 118, 1974.

14. Clarke HT: A Handbook of Organic Analysis, Edward Arnold (Pub) Ltd, London, p 129, 1960.

15. Dincer M, Ozdemir N, Cukurovali A, Yilmaz I. Benzoin thiosemicarbazone. Inter Uni Crystallo 2005; 61(4): 880-883.

16. Litefifield JT, Wilcoxon F. A simplified method of evaluation dose-effects experiment. J Pharmacol Exp Ther 1949; 96: 99113.

17. Abbot BJ. Bioassay of plant extract for anticancer activity. Cancer Treat Rep 1976; 60: 1007-1017.

18. Fernades DJ, Klubes P: A biochemical and pharmacological study of therapeutic synergism with 5-fluonounacil plus cyclophosphamide in murine L1210 Leukemia. Cancer Res 1979; 39: 1396-1404.

19. Rusia U, Sood SK. Medical Laboratory Technology: A procedure manual for routine diagonstic tests. Vol 1; 228 Ed. K.L. Mukherjee, Tata McGraw Hill Comp. Ltd. New Delhi. Chapter 10; p 218-280, 1988.

20. Hundson L, Hay FC. Isolation of normal peritoneal macrophages, In practical Immunology. 3rd ed, Black Well Science publ, Oxford London, p 26, 1989.

21. Clarkson BD, Burchenal JH. Preliminary screening of antineoplastic drugs. Prog Clin Cancer 1965; 1: 625-629.

22. Price VE, Greenfield RE. Anemia in cancer. Adv Cancer Res 1958; 5: 199-200.

23. Hogland HC. Hematological complication of cancer chemotherapy. Semin Oncol 1982; 9: 95-102.

24. Fenninger LD, Mider GB. Energy and nitrogen metabolism in cancer. Adv Cancer Res 1954; 2: 2229-2253.

25. Burger A. Medicinal Chemistry. Vol 2 (3rd ed), John Wiley and Sons, London, p 602-653, 1981.

26. Lee NN, Cadman EC, Michael IN, Michael C, Joseph R, Bertino Farber LR, Prosnitz LR. Randomized study comparing doxorubicin, cyclophosphamide, vincristine, methotrexate with leucovorin rescue and cytarabine (ACOMLA) with cyclophosphamide, doxorubicin, vincristine, prednisone and bleomycin (CHOP-B) in the treatment of diffuse histiocytic lymphoma. Cancer Treat Rep 1982; 66(6): 1279-1284. 